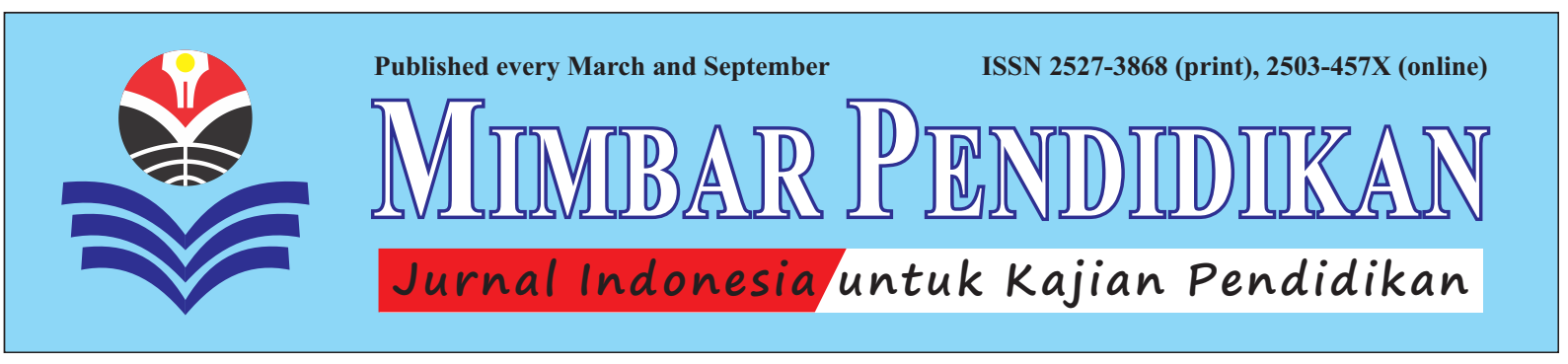

ROZA YULIDA, KAUSAR \& YULIA ANDRIANI

\title{
Penggunaan Model Pembelajaran Penemuan Terbimbing dalam Meningkatan Aktivitas dan Hasil Belajar Mahasiswa pada Matakuliah Penyuluhan dan Komunikasi Pertanian
}

\begin{abstract}
ABSTRAKSI: Penelitian ini untuk mengetahui peningkatan aktivitas belajar dan hasil belajar mahasiswa Jurusan Agribisnis pada matakuliah Penyuluhan dan Komunikasi Pertanian, dengan penerapan metode penemuan terbimbing. Penelitian ini adalah PTK (Penelitian Tindakan Kelas), yang dilakukan pada mahasiswa semester III (Ganjil) dan dilaksanakan selama 4 bulan. Hasil penelitian menunjukan bahwa aktivitas mahasiswa mengalami peningkatan dari siklus I ke siklus II pada enam indikator, yaitu: tanya-jawab antar mahasiswa; tanya-jawab antara mahasiswa dengan dosen; mengerjakan dan mendiskusikan LKM (Lembar Kerja Majasiswa); mempraktekan langkah-langkah metode penemuan terbimbing; menyajikan hasil kerja kelompok; serta menyimpulkan materi pelajaran bersama-sama dosen. Dalam menerapkan pembelajaran, sebaiknya dosen membuat perencanaan yang matang sehingga pembelajaran berjalan secara sistematis; dan membuat LKM yang lebih variatif.

KATA KUNCI: Aktivitas Belajar; Mahasiswa; Dosen; Hasil Belajar; Model Pembelajaran Penemuan Terbimbing.

ABSTRACT: "The Use of Guided Discovery Learning Model to Increase Students'Activity and Learning Outcomes in the Subject of Agricultural Communication and Extension". This research is to determine the increase in the learning activities and learning outcomes of Agribusiness Department stundents in the subject of Agricultural Communication and Extension, by implementing the guided discovery method. This is CAR (Clasroom Action Research) conduced to the $3 r d$ semester students and was carried out for 4 months. The research results showed that students' activity increased from the first cycle to the second cycle in six indicators: debriefing between students; debriefing between students and lecturers; working on and discussing student worksheet; practicing the guided steps of discovery model; presenting the results of group work; and drawing a conclusion of subject matter along with the lecturer. In applying the learning method, lecturers should make planning so that the learning goes systematically; and they should create more varied worksheet.
\end{abstract}

KEY WORD: Learning Activities; Students; Lecturers; Learning Outcomes; Guided Discovery Learning Model.

About the Authors: Roza Yulida, M.Si.; Kausar, M.Si.; dan Yulia Andriani, M.Si. adalah Staf Pengajar pada Jurusan Agribisnis, Fakultas Pertanian UNRI (Universitas Riau), Kampus Bina Widya, Jalan H.R. Soebrantas Km.12,5 Panam, Kota Pekanbaru, Provinsi Riau, Indonesia. Alamat emel penulis adalah: rozayulida@gmail.com, kausar_ur@yahoo.co.id, dan yulia. andriani@lecturer.unri.ac.id

How to cite this article? Yulida, Roza, Kausar \& Yulia Andriani. (2016). "Penggunaan Model Pembelajaran Penemuan Terbimbing dalam Meningkatan Aktivitas dan Hasil Belajar Mahasiswa pada Matakuliah Penyuluhan dan Komunikasi Pertanian" in MIMBAR PENDIDIKAN: Jurnal Indonesia untuk Kajian Pendidikan, Vol.1(2) September, pp.189-200. Bandung, Indonesia: UPI [Indonesia University of Education] Press, ISSN 2527-3868 (print) and 2503-457X (online).

Chronicle of the article: Accepted (June 19, 2016); Revised (August 17, 2016); and Published (September 30, 2016). 


\section{PENDAHULUAN}

Penyuluhan dan komunikasi pertanian merupakan ilmu pengetahuan umum yang memegang peranan penting dalam perkembangan pertanian di Indonesia. Oleh karena itu, matakuliah Penyuluhan dan Komunikasi Pertanian merupakan matakuliah wajib pada Jurusan Agribisnis, Fakultas Pertanian UNRI (Universitas Riau) di Kota Pekanbaru, Provinsi Riau, Indonesia. Berdasarkan pengalaman mengajar di Fakultas Pertanian UNRI, mahasiswa masih cenderung pasif, karena lebih banyak tergantung pada apa yang diperintahkan oleh dosen. Rendahnya aktivitas belajar mahasiswa pada matakuliah Penyuluhan dan Komunikasi Pertanian, menjadi salah satu penyebab rendahnya hasil belajar mahasiswa.

Dosen sebagai salah satu kunci utama dalam memajukan pendidikan harus mampu menggunakan berbagai metode pembelajaran. Proses pembelajaran harus lebih menarik perhatian mahasiswa, sehingga berdampak pada peningkatan hasil belajar, khususnya pada matakuliah Penyuluhan dan Komunikasi Pertanian. Untuk melakukan itu perlu dilakukan perubahan dalam penerapan metode pembelajaran. Salah satu alternatif metode pembelajaran yang dapat digunakan, yakni metode penemuan terbimbing. Di samping dapat mengembangkan kemampuan kognitif mahasiswa, metode ini juga dapat menumbuhkan aktivitas interaksi mahasiswa, baik dengan dosen maupun antar mahasiswa.

Robert J. Marzano (1992), dan dikutip juga dalam Markaban (2006), menyatakan bahwa metode penemuan terbimbing memiliki kelebihan, sebagai berikut: (1) Mahasiswa dapat berpartisipasi aktif dalam pembelajaran yang disajikan; (2) Menumbuhkan sekaligus menanamkan sikap menemukan atau mencari-temukan; (3) Mendukung kemampuan problem solving mahasiswa; (4) Memberikan wahana interaksi, baik antar mahasiswa maupun mahasiswa dengan dosen, dengan demikian siswa juga terlatih untuk menggunakan bahasa Indonesia yang baik dan benar; serta (5) Materi yang dipelajari dapat mencapai tingkat kemampuan yang tinggi dan lebih lama membekas, karena mahasiswa dilibatkan dalam proses menemukannya ( $c f$ Marzano, 1992; Markaban, 2006; Karim, 2011).

Penemuan terbimbing adalah metode dimana guru sebagai fasilitator dan pengarah; sedangkan siswa aktif melakukan kegiatan sesuai prosedur atau langkah kerja untuk mengembangakan rasa ingin tahunya. Dalam konteks ini, Jerome S. Bruner (1977) dan Diah E. Triningsih (2014) menjelaskan bahwa belajar penemuan pada akhirnya dapat meningkatkan penalaran dan kemampuan untuk berfikir secara bebas; melatih keterampilan kognitif siswa dengan cara menemukan dan memecahkan masalah yang ditemui dengan pengetahuan yang telah dimiliki; serta menghasilkan pengetahuan yang benar-benar bermakna bagi dirinya (Bruner, 1977; dan Triningsih, 2014).

Hasil penelitian Kristina Chaidir (2008) mengenai penerapan metode penemuan terbimbing dalam pembelajaran Matematika di SMAN (Sekolah Menengah Atas Negeri) Padang, Sumatera Barat, Indonesia, menyimpulkan bahwa pembelajaran Matematika, melalui metode penemuan terbimbing, dapat meningkatkan aktivitas belajar siswa dan hasil belajar siswa pada mata pelajaran Matematika (Chaidir, 2008). Hal senada juga dari hasil penelitian Haryani Hasibuan et al. (2014), yang menyimpulkan bahwa setelah diterapkannya metode penemuan terbimbing pada pembelajaran Matematika di kelas XI IPA (Ilmu Pengetahuan Alam) SMAN 1 Lubuk Alung, diperoleh pemahaman Matematika siswa yang lebih baik bila dibandingkan dengan pemahaman Matematika siswa yang mengikuti pembelajaran secara konvensional (Hasibuan et al., 2014).

Nana Sudjana (2009) mengungkapkan bahwa hasil belajar merupakan kemampuankemampuan yang dimiliki siswa setelah 
menerima pengalaman belajar. Dengan adanya kegiatan belajar akan menghasilkan perubahan pada diri siswa atau subjek didik (Sudjana, 2009). Berkaitan dengan kemampuan yang diperoleh dari hasil belajar tersebut, B.S. Bloom et al. (1956), sebagaimana dikutif oleh Nana Sudjana juga, membagi hasil belajar dalam 3 ranah, yaitu: kognitif atau pengetahuan, afektif atau sikap, dan psikomotor atau keterampilan (Bloom et al., 1956; dan Sudjana, 2009).

Menurut Margono Slamet (2009), ilmu Penyuluhan Pembangunan dapat digunakan sebagai alat rekayasa pembangunan sosial, sehingga berkemampuan untuk membentuk pola perilaku tertentu dalam masyarakat, yang dalam jangka waktu tertentu dapat dijadikan sebagai syarat untuk memperbaiki kualitas kehidupan rakyat (Slamet, 2009). Sementara itu, mahasiswa sebagai calon intelektual akan berinteraksi dengan masyarakat dan menjadi pendamping masyarakat. Mereka (para mahasiswa) perlu memiliki pemahaman dan kemampuan untuk dapat melakukan penyuluhan dan komunikasi di masyarakat.

Oleh karena itu, agar mahasiswa memiliki pemahaman dan kemampuan tersebut, dengan metode pembelajaran penemuan terbimbing diharapkan dapat menemukan konsep-konsep penyuluhan dan komunikasi pertanian dengan bimbingan dosen. Hal ini akan berbeda pengalaman yang bisa didapatkan mahasiswa, jika mereka hanya mendengar, dibandingkan dengan pengalaman mereka menemukan sendiri ( $c f$ Sudjana, 2009; dan Yamin, 2009).

Adapun tujuan penelitian ini adalah sebagai berikut: (1) Mengetahui peningkatan aktivitas belajar mahasiswa Jurusan Agribisnis, Fakultas Pertanian UNRI pada matakuliah Penyuluhan dan Komunikasi Pertanian, dengan penerapan metode penemuan terbimbing; serta (2) Mengetahui peningkatan hasil belajar mahasiswa Jurusan Agribisnis, Fakultas Pertanian UNRI pada matakuliah Penyuluhan dan Komunikasi
Pertanian, dengan penerapan metode penemuan terbimbing.

\section{METODE PENELITIAN}

Lokasi, Waktu, dan Subjek Penelitian.

Penelitian ini dilaksanakan pada Program

Studi Agribisnis, Jurusan Agribisnis, Fakultas

Pertanian UNRI (Universitas Riau) di

Kota Pekanbaru, Provinsi Riau, Indonesia, pada Semester III atau Ganjil. Penelitian dilaksanakan selama 4 bulan. Penelitian disesuaikan dengan jadwal perkuliahan di Fakultas Pertanian UNRI, dengan waktu pertemuan satu kali dalam satu minggu.

Penelitian ini merupakan PTK (Penelitian Tindakan Kelas), karena ianya merupakan penelitian tindakan yang dilakukan dengan tujuan untuk memperbaiki kualitas proses dan hasil belajar mahasiswa ( $c f$ McNiff, 1991; Kasbolah, 1999; Mills, 2003; dan Hamid, 2009). Matakuliah yang akan dilakukan penelitian adalah matakuliah Penyuluhan dan Kounikasi Pertanian, yang merupakan salah satu matakuliah wajib mahasiswa Jurusan Agribisnis, Fakultas Pertanian UNRI. Subjek dalam penelitian ini adalah mahasiswa Jurusan Agribisnis, yang duduk di Semester III atau Ganjil.

\section{Prosedur Penelitian, Instrumen,} dan Teknik Pengumpulan Data. Siklus penelitian tindakan kelas ini dilaksanakan dengan tindakan kegiatan yang terdiri dari empat tahap, yaitu: perencanaan, tindakan, pengamatan, dan refleksi (McNiff, 1991; Kasbolah, 1999; Mills, 2003; dan Hamid, 2009). Instrumen penelitian terdiri dari lembar observasi aktivitas mahasiswa, lembar tes hasil belajar, dan panduan catatan lapangan.

Data tentang peningkatan aktivitas belajar mahasiswa diperoleh dari hasil pengamatan yang dilakukan. Data tentang peningkatan hasil belajar mahasiswa diperoleh melalui tes hasil belajar mahasiswa. Selain itu, mahasiswa juga diberikan tugas-tugas untuk menunjang pelaksanaan penelitian untuk meningkatkan aktivitas dan hasil belajar mahasiswa. 
Tabel 1:

Persentase Peningkatan Aktivitas Mahasiswa dalam Pembelajaran dengan Menerapkan Metode Penemuan Terbimbing pada Siklus I

\begin{tabular}{|c|c|c|c|c|c|c|c|c|}
\hline \multirow{3}{*}{ Kategori } & \multirow{3}{*}{ Aktivitas yang Diamati } & \multicolumn{7}{|c|}{ Jumlah dan Persentase Mahasiswa } \\
\hline & & \multicolumn{2}{|c|}{ P1 } & \multicolumn{2}{|c|}{$\mathbf{P 2}$} & \multicolumn{2}{|c|}{ P3 } & \multirow{2}{*}{$\frac{\text { Rata-rata }}{\%}$} \\
\hline & & Jlh & $\%$ & Jlh & $\%$ & Jlh & $\%$ & \\
\hline A & $\begin{array}{l}\text { Tanya jawab antar mahasiswa dan } \\
\text { antara mahasiswa dengan dosen. }\end{array}$ & 28 & 42 & 36 & 55 & 40 & 61 & 53 \\
\hline $\mathrm{B}$ & $\begin{array}{l}\text { Mengerjakan dan mendiskusikan LKM } \\
\text { yang diberikan dalam kelompok. }\end{array}$ & 54 & 82 & 58 & 88 & 60 & 91 & 87 \\
\hline $\mathrm{C}$ & $\begin{array}{l}\text { Mempraktekan langkah-langkah metode } \\
\text { penemuan terbimbing sesuai petunjuk } \\
\text { LKM. }\end{array}$ & 52 & 78 & 54 & 82 & 58 & 88 & 83 \\
\hline $\mathrm{D}$ & $\begin{array}{l}\text { Menyajikan hasil kerja kelompok di } \\
\text { depan kelas. }\end{array}$ & 12 & 18 & 16 & 24 & 20 & 30 & 24 \\
\hline $\mathrm{E}$ & $\begin{array}{l}\text { Mengemukakan pendapat dalam diskusi } \\
\text { dengan kelompok lain. }\end{array}$ & 8 & 12 & 10 & 15 & 12 & 18 & 15 \\
\hline $\mathrm{F}$ & $\begin{array}{l}\text { Menyimpulkan materi pelajaran } \\
\text { bersama-sama dengan dosen. }\end{array}$ & 16 & 24 & 38 & 58 & 42 & 64 & 48 \\
\hline
\end{tabular}

Keterangan: P1 = Pertemuan Pertama; P2 = Pertemuan Kedua; P3 = Pertemuan Ketiga; Jlh = Jumlah; $\mathrm{LKM}=$ Lembar Kerja Mahasiswa.

Indikator Keberhasilan. Indikator keberhasilan dalam penelitian ini merujuk pada empat hal, sebagai berikut:

Pertama, interpretasi aktivitas belajar dikategorikan sebagai berikut: $0 \% \leq \mathrm{P}<20 \%$ $=$ kurang sekalli; $20 \% \leq \mathrm{P}<40 \%=$ kurang; $40 \% \leq \mathrm{P}<60 \%=$ cukup; $60 \% \leq \mathrm{P}<80 \%=$ baik; dan $80 \% \leq \mathrm{P}<100 \%$ = baik sekali.

Kedua, aktivitas mahasiswa untuk indikator tanya-jawab, mengerjakan dan mendiskusikan lembar kerja dalam kelompok, mempraktekan langkah-langkah penemuan terbimbing, serta menyimpulkan materi bersama-sama dengan dosen digolongkan ke dalam kriteria aktivitas baik $(60 \%-80 \%)$.

Ketiga, aktivitas mahasiswa untuk indikator lainnya, yaitu menyajikan hasil kerja kelompok di depan kelas dan mengemukakan pendapat dalam diskusi dengan kelompok lain, apabila mencapai $40 \%$ - 60\% sudah dapat dikategorikan cukup. Hal ini disebabkan karena bentuk aktivitas yang diobservasi, dan mengingat waktu tatap muka yang hanya $2 \times 50$ menit setiap pertemuan.
Keempat, hasil belajar pada penelitian ini dikatakan meningkat apabila $70 \%$ dari seluruh mahasiswa memperoleh nilai lulus dalam range $\geq 66$.

\section{HASIL PENELITIAN}

\section{Hasil Observasi Aktivitas Mahasiswa}

Siklus I. Hasil observasi terhadap aktivitas mahasiswa dalam pembelajaran Penyuluhan dan Komunikasi Pertanian, dengan menerapkan metode penemuan terbimbing, disajikan pada tabel 1.

Tabel 1 menunjukan bahwa pada pertemuan pertama, aktivitas mahasiswa dalam tanya-jawab antar mahasiswa dan antara mahasiswa dengan dosen tergolong kategori "cukup", yaitu 28 orang atau 42 persen. Kurangnya aktivitas tanya-jawab menunjukan bahwa masih banyak mahasiswa yang belum aktif dalam pembelajaran, belum berani mengemukakan ide atau gagasan mereka untuk menjawab pertanyaan mahasiswa lain dan pertanyaan dosen. Mahasiswa masih ada yang diam, karena takut salah dalam mengungkapkan hasil pemikiran mereka, mahasiswa juga belum 
terbiasa belajar dalam suasana diskusi.

Jumlah mahasiswa yang mengerjakan dan mendiskusikan LKM (Lembar Kerja Mahasiswa) sudah tergolong kategori "baik sekali”. Artinya, aktivitas diskusi sudah berjalan baik, dilihat dari segi jumlah mahasiswa yang terlibat dalam diskusi. Kondisi yang baik juga terlihat pada aktivitas mahasiswa dalam mempraktekan langkahlangkah metode penemuan terbimbing, sesuai petunjuk dalam LKM. Meski demikian, jumlah mahasiswa yang terlibat dalam diskusi masih belum mencapai 100 persen, karena masih ada mahasiswa yang lebih bergantung pada teman satu kelompok yang lebih pintar, sehingga enggan bekerja dalam kelompok.

Jumlah mahasiswa yang menyajikan hasil kerja dalam kelompok di depan kelas, pada pertemuan pertama, sebanyak 12 orang atau 18 persen. Dibandingkan dengan jumlah seluruh mahasiswa, jumlah yang menyajikan hasil kerja kelompok memang tergolong rendah, tetapi jumlah 12 orang yang aktif menyajikan hasil kerja kelompok tersebut sudah dapat dikatakan "baik". Sebab, mengingat waktu yang hanya $2 \times 50$ menit satu pertemuan, tidak memungkinkan seluruh mahasiswa untuk maju ke depan kelas.

Aktivitas mahasiswa mengemukakan pendapat dalam diskusi dengan kelompok lain tergolong kategori "sangat kurang", yaitu hanya sebanyak 8 orang atau 12 persen. Artinya, perlu upaya yang lebih baik lagi dalam memotivasi mahasiswa agar mampu mengemukakan pendapat dalam diskusi, sesuai dengan hasil penemuan dalam kelompok.

Aktivitas mahasiswa dalam menyimpulkan materi pelajaran bersama-sama dengan dosen sudah tergolong "cukup", yaitu sebanyak 16 orang atau 24 persen. Akan tetapi, ada mahasiswa mulai tidak konsentrasi dalam belajar, yang ditandai dengan adanya mahasiswa yang bercerita di luar topik pembelajaran, dan hanya berharap bisa mencontek hasil kesimpulan teman yang lain.
Peningkatan aktivitas mulai terlihat pada pertemuan kedua. Jumlah mahasiswa yang terlibat dalam tanya-jawab sudah meningkat menjadi 18 orang, artinya sudah mendekati kategori "cukup". Aktivitas mahasiswa dalam mengerjakan dan mendiskusikan LKM, yang diberikan dalam kelompok, tergolong kategori "baik"; demikian juga dengan aktivitas mahasiswa dalam mempraktekan langkah-langkah metode penemuan terbimbing.

Jumlah mahasiswa yang menyajikan hasil kerja di depan kelas mulai meningkat menjadi 16 orang. Hal ini terjadi karena sudah ada dua anggota dalam satu kelompok yang berani maju ke depan, namun masih ada anggota kelompok yang enggan maju bersama teman satu kelompok di depan kelas. Aktivitas mengemukakan pendapat dalam diskusi dengan kelompok lain, dimana jumlah mahasiswa yang terlibat dalam aktivitas menyimpulkan materi pelajaran bersama-sama dosen, juga meningkat secara signifikan, dari 16 orang pada pertemuan pertama menjadi 38 orang pada pertemuan kedua.

Pada pertemuan ketiga, jumlah mahasiswa yang terlibat dalam tanya-jawab meningkat menjadi 40 orang, artinya semakin banyak mahasiswa yang aktif dalam pembelajaran. Jumlah mahasiswa yang mengerjakan dan mendiskusikan LKM, yang diberikan dalam kelompok, semakin "baik", karena dari 64 mahasiswa, hanya dua mahasiswa saja yang masih pasif dalam diskusi. Jumlah mahasiswa yang mempraktekan langkahlangkah metode penemuan terbimbing juga tetap tergolong kategori "baik".

Untuk aktivitas menyajikan hasil kerja kelompok di depan kelas, jumlah mahasiswa yang terlibat masih kurang, tetapi sudah terjadi peningkatan dari dua pertemuan sebelumnya, yang mana jumlah mahasiswa yang ikut menyajikan sebanyak 20 orang. Pada pertemuan ini, jumlah anggota kelompok yang maju menyampaikan hasil kelompok umumnya dua orang anggota dalam satu kelompok, dan masing-masing 
Tabel 2:

Hasil Belajar Mahaisiswa pada Pembelajaran Penyuluhan dan Komunikasi Pertanian dengan Menggunakan Metode Penemuan Terbimbing Siklus I

\begin{tabular}{lccc}
\hline Kategori & Jumlah Mahasiswa & Persentase & Ketuntasan \\
\hline Nilai $\geq 66$ & 36 & 58.06 & Lulus \\
Nilai $<66$ & 30 & 41.94 & Tidak Lulus \\
\hline
\end{tabular}

anggota kelompok seluruhnya sudah bersedia maju berkomunikasi di depan kelas. Meskipun tidak semua anggota kelompok berbicara menyajikan materi, tetapi kehadiran mahasiswa di depan kelas lebih dari satu orang menggambarkan bahwa mahasiswa sudah mulai aktif dalam kegiatan menyajikan hasil kerja kelompok.

Pada aktivitas menyimpulkan materi pelajaran bersama-sama dosen, jumlah mahasiswa yang terlibat meningkat dari pertemuan sebelumnya. Jumlah mahasiswa yang terlibat dalam menyimpulkan materi dan pelajaran bersama-sama dosen pada pertemuan ketiga siklus pertama mencapai 42 orang atau 64 persen. Pada pertemuan ketiga ini masih ada yang diam dan hanya menyaksikan mahasiswa lainya bersama dosen menyimpulkan materi pelajaran. Melihat kondisi tersebut, dosen mengingatkan mahasiswa agar lebih serius dalam belajar agar mampu meningkatkan pemahaman konsep.

Secara umum, pada siklus I aktivitas mahasiswa dalam menyajikan hasil kerja kelompok di depan kelas dan mengemukakan pendapat dalam diskusi dengan kelompok lain sudah "cukup baik". Aktivitas mahasiswa mengerjakan dan mendiskusikan LKM dan mempraktekan langkah-langkah metode penemuan terbimbing sudah tergolong "baik sekali". Aktivitas yang tergolong kategori "cukup", yaitu jumlah mahasiswa yang terlibat dalam tanya-jawab dan menyimpulkan materi pelajaran bersamasama dosen.

Hasil Belajar Mahasiswa Siklus I. Hasil belajar mahasiswa pada penelitian ini dilihat dari skor pemahaman konsep Penyuluhan dan Komunikasi Pertanian pada tes yang dilaksanakan di akhir siklus I. Penilaian dilakukan sesuai dengan kriteria dan skala yang telah ditetapkan. Hasil belajar mahasiswa pada siklus I dapat dilihat pada tabel 2.

Jumlah mahasiswa yang lulus pada siklus I sebanyak 36 orang atau 58.06 persen. Jumlah tersebut belum mencapai kriteria yang diharapkan pada penelitian ini, yaitu 70 persen. Jumlah mahasiswa yang belum lulus juga masih banyak, yaitu 30 orang. Hal ini menandakan bahwa perlu perbaikan dalam pembelajaran agar mahasiswa bisa lebih memahami pokok bahasan.

Mahasiswa belum mampu mengenali urutan jawaban soal, sehingga hasil perumusan mahasiswa salah. Demikian juga kemampuan mahasiswa dalam mendeskripsikan hasil jawaban tentang konsep yang sedang dipelajari. Dalam penarikan kesimpulan masih memerlukan bimbingan, karena belum semua mahasiswa mampu menyimpulkan hasil penemuan dengan metode penemuan terbimbing.

Pada akhir siklus I, mahasiswa yang memperoleh nilai termasuk dalam kategori "lulus". Jawaban mahasiswa menunjukan bahwa dalam menyusun jawaban, mahasiswa menuliskan konsep dengan benar. Mahasiswa menjelaskan ciri-ciri konsep dan menjelaskan apa yang ditanya pada soal. Di akhir jawaban, mahasiswa menuliskan kesimpulan dari hasil jawaban yang diperoleh, sehingga menggambarkan kemampuan mahasiswa dalam mendeskripsikan hasil jawaban.

Hasil Observasi Aktivitas Mahasiswa Siklus II. Selama siklus II, dosen melakukan observasi untuk mengamati jalannya 
Tabel 3:

Persentase Peningkatan Aktivitas Mahasiswa dalam Pembelajaran dengan Menerapkan Metode Penemuan Terbimbing pada Siklus II

\begin{tabular}{|c|c|c|c|c|c|c|c|c|c|c|}
\hline \multirow{3}{*}{ Kategori } & \multirow{3}{*}{ Aktivitas yang Diamati } & \multicolumn{9}{|c|}{ Jumlah dan Persentase Siswa } \\
\hline & & \multicolumn{2}{|c|}{ P I } & \multicolumn{2}{|c|}{ P II } & \multicolumn{2}{|c|}{ P III } & \multicolumn{2}{|c|}{ P IV } & \multirow{2}{*}{$\frac{\text { Rata-rata }}{\%}$} \\
\hline & & Jlh & $\%$ & Jlh & $\%$ & Jlh & $\%$ & Jlh & $\%$ & \\
\hline A & $\begin{array}{l}\text { Tanya-jawab antar } \\
\text { mahasiswa dan antara } \\
\text { mahasiswa dengan dosen. }\end{array}$ & 39 & 59 & 40 & 61 & 44 & 67 & 50 & 76 & 65 \\
\hline B & $\begin{array}{l}\text { Mengerjakan dan } \\
\text { mendiskusikan LKM yang } \\
\text { diberikan dalam kelompok. }\end{array}$ & 66 & 100 & 64 & 97 & 66 & 100 & 66 & 100 & 99 \\
\hline $\mathrm{C}$ & $\begin{array}{l}\text { Mempraktekan langkah- } \\
\text { langkah metode penemuan } \\
\text { terbimbing sesuai petunjuk } \\
\text { LKM. }\end{array}$ & 66 & 100 & 64 & 97 & 66 & 100 & 66 & 100 & 99 \\
\hline $\mathrm{D}$ & $\begin{array}{l}\text { Menyajikan hasil kerja } \\
\text { kelompok di depan kelas. }\end{array}$ & 14 & 21 & 17 & 26 & 22 & 33 & 24 & 36 & 29 \\
\hline $\mathrm{E}$ & $\begin{array}{l}\text { Mengemukakan pendapat } \\
\text { dalam diskusi dengan } \\
\text { kelompok lain. }\end{array}$ & 14 & 21 & 15 & 23 & 15 & 23 & 24 & 36 & 26 \\
\hline $\mathrm{F}$ & $\begin{array}{l}\text { Menyimpulkan materi } \\
\text { pelajaran bersama-sama } \\
\text { dengan dosen. }\end{array}$ & 36 & 55 & 63 & 95 & 42 & 64 & 66 & 100 & 78 \\
\hline
\end{tabular}

Keterangan: P1 = Pertemuan I; P2 = Pertemuan II; P3 = Pertemuan III; P4 = Pertemuan IV; Jlh = Jumlah; dan $\mathrm{LKM}=$ Lembar Kerja Mahasiswa.

pembelajaran, dengan menerapkan metode penemuan terbimbing. Hasil observasi terhadap aktivitas mahasiswa dalam pembelajaran Penyuluhan dan Komunikasi Pertanian, dengan menerapkan metode penemuan terbimbing, dapat disajikan pada tabel 3 .

Tabel 3 menunjukan bahwa pada pertemuan pertama, aktivitas mahasiswa dalam tanyajawab antar mahasiswa dan antara mahasiswa dengan dosen terjadi peningkatan, yaitu tergolong kategori "cukup" hingga "baik sekali”, yaitu 39 (59\%) pada pertemuan pertama dan $50(76 \%)$ pada pertemuan keempat. Mahasiswa sudah mulai aktif selama proses pembelajaran, disebabkan dosen terus mendampingi dan memotivasi agar terlibat selama diskusi kelompok dan menanyakan jika ada hal-hal yang sulit untuk dipahami.

Aktivitas mengerjakan dan mendiskusikan LKM (Lembar Kerja Mahasiswa), mempraktekan langkah-langkah metode penemuan terbimbing sudah tergolong kategori "baik sekali”, bahkan seluruh mahasiswa (100\%) terlibat dalam aktivitas tersebut. Ini menunjukan bahwa semua mahasiswa telah aktif dalam proses pembelajaran.

Pada aktivitas menyajikan hasil kerja kelompok di depan kelas, mengemukakan pendapat dalam diskusi, dan menyajikan hasil kerja kelompok mengalami peningkatan. Terjadinya peningkatan aktivitas mahasiswa, karena mereka sudah berani mengungkapkan pendapatnya dan tidak takut salah atau tidak mampu menjawab pertanyaan. Pada saat diskusi, dosen memberi motivasi bahwa tidak perlu takut salah atau tidak mampu menjawab, karena jika tidak bisa dijawab, boleh dijawab oleh teman lain, atau akan difasilitiasi oleh dosen.

Kelompok yang akan menyajikan hasil kerja kelompoknya di depan kelas sudah atas keinginan mahasiswa sendiri. Dosen 
Tabel 4:

Hasil Belajar Mahasiswa pada Pembelajaran Penyuluhan dan Komunikasi Pertanian dengan Menggunakan Metode Penemuan Terbimbing Siklus II

\begin{tabular}{lccc}
\hline Kategori & Jumlah Mahasiswa & Persentase & Ketuntasan \\
\hline Nilai $\geq 66$ & 51 & 78.46 & Lulus \\
Nilai $<66$ & 15 & 21.54 & Tidak Lulus \\
\hline
\end{tabular}

Tabel 5:

Perbandingan Aktivitas Mahasiswa dalam Proses Pembelajaran dengan Metode Penemuan Terbimbing Siklus I dan Siklus II

\begin{tabular}{clccc}
\hline No & \multicolumn{1}{c}{ Aktivitas yang Diamati } & SIklus I (\%) & Siklus II (\%) & Peningkatan (\%) \\
\hline 1 & $\begin{array}{l}\text { Tanya-jawab antar mahasiswa dan antara } \\
\text { mahasiswa dengan dosen. }\end{array}$ & 53 & 65 & 12 \\
\hline 2 & $\begin{array}{l}\text { Mengerjakan dan mendiskusikan LKM yang } \\
\text { diberikan dalam kelompok. }\end{array}$ & 87 & 99 & 12 \\
\hline $\begin{array}{l}\text { Mempraktekan langkah-langkah metode } \\
\text { penemuan terbimbing sesuai petunjuk pada } \\
\text { LKM. }\end{array}$ & 83 & 99 & 16 \\
\hline 4 & Menyajikan hasil kerja kelompok di depan kelas. & 24 & 29 & 5 \\
\hline 5 & $\begin{array}{l}\text { Mengemukakan pendapat dalam diskusi dengan } \\
\text { kelompok lain. }\end{array}$ & 15 & 26 & 11 \\
\hline 6 & $\begin{array}{l}\text { Menyimpulkan materi pelajaran bersama-sama } \\
\text { dengan dosen. }\end{array}$ & 48 & 78 & 30 \\
\hline
\end{tabular}

tidak lagi menunjuk kelompok yang akan tampil, namun dipersilakan kepada kelompok mahasiswa yang mau untuk tampil terlebih dahulu. Perubahan ini cukup menggembirakan mengingat selama ini, sulitnya memotivasi mahasiswa untuk berani tampil di depan kelas.

Untuk aktivitas menyimpulkan materi pelajaran bersama-sama dengan dosen, juga tergolong "baik sekali". Kondisi ini terlihat ketika semua mahasiswa aktif menyimpulkan materi pelajaran dan sudah lebih fokus dalam mengikuti pembelajaran.

Hasil Belajar Mahasiswa Siklus II. Pada siklus II, penilaian hasil belajar juga dilakukan dengan merujuk pada kriteria pemahaman konsep mahasiswa. Hasil belajar mahasiswa pada siklus II dapat dilihat pada tabel 4.

Jumlah mahasiswa yang lulus pada siklus II sebanyak 51 orang atau 78.46 persen. Artinya, jumlah mahasiswa yang lulus pada pembelajaran sudah lebih dari 70 persen. Kondisi tersebut sudah melebihi kriteria yang ditargetkan pada penelitian ini. Rata-rata nilai mahasiswa 72.92, yang berarti bahwa sebagian besar mahasiswa nilainya sudah lebih dari nilai minimal yang ditetapkan, yaitu 66.

Selama pembelajaran siklus II dilaksanakan, secara bertahap, tingkat pemahaman konsep mahasiswa semakin meningkat, yang ditandai dengan meningkatnya kemampuan mahasiswa dalam mendefinisikan konsep. Dalam hal penarikan kesimpulan, mahasiswa dapat melakukannya sesuai dengan hasil penemuan yang mereka lakukan dalam menyelesaikan soal yang diberikan.

\section{PEMBAHASAN}

\section{Aktivitas Belajar Mahasiswa. Data} tentang aktivitas mahasiswa yang diperoleh dari hasil pengamatan pada siklus I dan siklus II telah terjadi peningkatan. Peningkatan tersebut dapat dilihat pada tabel 5 .

Aktivitas tanya-jawab antar mahasiswa dan antara mahasiswa dengan dosen, dapat dilihat dari semakin antusiasnya mahasiswa 
Tabel 6:

Hasil Belajar Mahasiswa pada Pembelajaran Matematika dengan Menerapkan Metode Penemuan Terbimbing Siklus I dan II

\begin{tabular}{lccccc}
\hline \multirow{2}{*}{ Kategori } & \multicolumn{2}{c}{ Jumlah Mahasiswa } & \multicolumn{2}{c}{ Persentase } & \multirow{2}{*}{ Ketuntasan } \\
\cline { 2 - 5 } & Siklus I & Siklus II & Siklus I & Siklus II & \\
\hline Nilai $\geq 66$ & 36 & 51.06 & 51 & 78.46 & Lulus \\
Nilai $<66$ & 30 & 48.94 & 15 & 21.54 & Tidak Lulus \\
\hline
\end{tabular}

dalam mengikuti pembelajaran, sehingga ketika menemukan kesulitan dalam penyelidikan, mahasiswa langsung bertanya kepada dosen ataupun teman satu kelompok. Mahasiswa yang sudah memahami materi yang sedang dibahas dapat menjawab, baik pertanyaan dari dosen maupun mahasiswa lainnya. Menurut Syaiful Bahri Djamarah (2000), salah satu aktivitas adalah partisipasi siswa dalam melaksanakan tugas belajarnya melalui berbagai cara. Salah satu cara yang dilakukan oleh mahasiswa adalah tanyajawab antar mahasiswa dan antara mahasiswa dengan dosen (Djamarah, 2000).

Aktivitas mahasiswa dalam mengerjakan dan mendiskusikan LKM (Lembar Kerja Mahasiswa), sejak awal siklus I hingga akhir siklus II, sudah tergolong "baik". Kondisi ini didukung oleh rangkaian kegiatan penemuan dalam LKM, yang harus dilakukan oleh mahasiswa, sehingga merangsang mahasiswa untuk aktif dalam berdiskusi dan mengerjakan soal.

Dalam hal aktivitas menyajikan hasil kerja dalam kelompok dan mengemukakan pendapat dalam diskusi dengan kelompok lain, masih tergolong "kurang”. Karena memang mahasiswa yang sudah biasa untuk menyampaikan pendapat adalah mereka yang selalu berani untuk tampil. Namun, keaktifan mahasiswa untuk menyampaikan hasil kerja kelompok di depan kelas sebenarnya sudah meningkat dan yang lebih menggembirakan adalah sudah ada motivasi dari mahasiswa sendiri untuk mau tampil di depan kelas, tanpa perlu disuruh oleh dosen.

Pada aktivitas menyimpulkan materi pelajaran bersama dosen selama pembelajaran berlangsung terus mengalami peningkatan. Bahkan pada akhir pembelajaran menggunakan metode penemuan terbimbing, seluruh mahasiswa terlibat dalam penyimpulan materi pelajaran.

Hasil Belajar Mahaiswa. Di samping mengetahui peningkatan aktivitas belajar mahasiswa, pada penelitian ini juga dilihat peningkatan hasil belajar mahasiswa yang dilihat dari kemampuan pemahaman konsep. Pembahasan tentang hasil belajar mahasiswa, yang dilaksanakan pada siklus I dan II, dapat dilihat dalam tabel 6 .

Hasil belajar mahasiswa pada pembelajaran dengan menerapkan metode penemuan terbimbing mengalami peningkatan dari siklus I ke siklus II. Jumlah mahasiswa yang lulus pada siklus I sebanyak 36 orang atau 51.06 persen dari 66 siswa yang ada. Pada siklus I, hasil belajar yang diperoleh masih kurang dan belum mencapai kriteria yang diharapkan pada penelitian ini.

Setelah dilakukan perbaikan, sesuai dengan hasil refleksi yang dilakukan, hasil belajar mahasiswa mengalami peningkatan pada siklus II, yang mana jumlah mahasiswa yang lulus meningkat sebesar 27.40 atau mencapai 78.46 persen. Hasil belajar mahasiswa pada siklus I mencapai rata-rata 66.23; dan pada siklus II meningkat hingga mencapai rata-rata 72.92. Hal ini menunjukan bahwa sebagian besar mahasiswa sudah dapat mencapai lulus dalam belajar.

Meningkatnya hasil belajar mahasiswa, dilihat dari semakin baiknya kemampuan mahasiswa dalam mendefinisinikan, 
mengidentifikasikan konsep, mengenali prosedur penemuan yang benar, dan mengambil kesimpulan dari hasil penemuan (Sudjana, 2006). Hal ini juga merupakan pertanda meningkatnya kemampuan mahasiswa setelah menerima pengalaman belajar pada pembelajaran yang menerapkan metode penemuan terbimbing.

\section{KESIMPULAN}

Setelah melaksanakan PTK (Penelitian Tindakan Kelas), dengan menerapkan metode penemuan terbimbing, pada matakuliah Penyuluhan dan Komunikasi Pertanian diperoleh kesimpulan sebagai berikut:

Penerapan metode penemuan terbimbing dapat meningkatkan aktivitas belajar mahasiswa. Aktivitas mahasiswa mengalami peningkatan dari siklus I ke siklus II pada enam indikator yang diamati, yaitu: (1) tanya-jawab antar mahasiswa; (2) tanyajawab antara mahasiswa dengan dosen; (3) mengerjakan dan mendiskusikan LKM atau Lembar Kerja Mahasiswa; (4) mempraktekan langkah-langkah metode penemuan terbimbing; (5) menyajikan hasil kerja kelompok; serta (5) menyimpulkan materi pelajaran bersama-sama dosen.

Penerapan metode penemuan terbimbing dapat meningkatkan hasil belajar mahasiswa. Pada siklus I, jumlah mahasiswa yang tuntas mencapai 36 orang atau 51.06 persen; sedangkan pada siklus II, jumlah mahasiswa yang tuntas meningkat menjadi 51 orang atau 78.46 persen.

Berdasarkan hasil PTK yang dilaksanakan dapat dikemukakan saran-saran sebagai berikut:

Pertama, dalam menerapkan pembelajaran dengan metode penemuan terbimbing, sebaiknya dosen membuat perencanaan yang matang sehingga pembelajaran berjalan secara sistematis. Perencanaan yang matang menjadikan pemanfaatan waktu berjalan efektif.

Kedua, untuk membimbing mahasiswa melakukan penemuan, dosen disarankan membuat LKM yang lebih variatif guna memancing mahasiswa untuk menemukan jawaban yang benar.

Ketiga, pembelajaran menerapkan metode penemuan terbimbing dapat meningkatkan aktivitas dan hasil belajar mahasiswa pada Jurusan Agribisnis, Fakultas Pertanian UNRI (Universitas Riau) di Kota Pekanbaru, Provinsi Riau, Indonesia. Peneliti selanjutnya meyarankan untuk memberikan inovasiinovasi baru agar penerapan metode penemuan terbimbing menjadi lebih menarik bagi mahasiswa. ${ }^{1}$

\section{Referensi}

Bloom, B.S. et al. (1956). Taxonomy of Educational Objectives, Handbook I: Cognitive Domain. New York: David McKay.

Bruner, Jerome S. (1977). The Process of Education. London: Harvard University Press.

Chaidir, Kristina. (2008). "Penerapan Metode Penemuan Terbimbing dalam Pembelajaran Matematika di SMAN Padang”. Tesis Tidak Diterbitkan. Padang: UNP [Universitas Negeri Padang].

Djamarah, Syaiful Bahri. (2000). Guru dan Anak Didik dalam Interaksi Edukatif. Jakarta: Rineka Cipta.

Hamid, Ahmad Abu. (2009). "Penelitian Tindakan, Penelitian Kelas, dan Penelitian Tindakan Kelas". Tersedia secara online di: http://staff.uny.ac.id/ sites/default/files/130814851/Penelitian $\% 20$ Tindakan\%20Kelas.pdf [diakses di Kota Pekanbaru, Indonesia: 2 Mei 2016].

Hasibuan, Haryani et al. (2014). "Penerapan Metode Penemuan Terbimbing pada Pembelajaran Matematika Kelas XI IPA SMAN 1 Lubuk Alung”' dalam Jurnal Pendidikan Matematika, Vol.3, No.1 [Maret], hlm.38-44, ISSN 30081968.

Karim, Asrul. (2011). "Penerapan Metode Penemuan Terbimbing dalam Pembelajaran Matematika untuk Meningkatkan Pemahaman Konsep dan Kemampuan Berpikir Kritis Siswa Sekolah Dasar". Tersedia secara online di: file:///C:/Users/

${ }^{1}$ Pernyataan: Dengan ini, kami menyatakan bahwa artikel ini adalah karya asli kami sendiri, ianya bukan hasil jiplakan atau perbuatan plagiat, karena sumber-sumber rujukan yang kami kutip dinyatakan secara jelas dalam Daftar Rujukan atau Referensi. Artikel ini juga belum pernah direviu dan belum pernah diterbitkan oleh jurnal ilmiah lain. 
acer/Downloads/37-52-1-PB.pdf [diakses di Kota Pekanbaru, Indonesia: 2 Mei 2016].

Kasbolah, Kasihani. (1999). Penelitian Tindakan Kelas (PTK). Jakarta: Penerbit IBRD.

Markaban. (2006). Model Pembelajaran Matematika dengan Pendekatan Penemuan Terbimbing. Yogyakarta: Pusat Pengembangan dan Penataran Guru Matematika, Departemen Pendidikan Nasional.

Marzano, Robert J. (1992). A Different Kind of Classroom: Teaching with Dimensions of Learning. Alexandria, VA: ASCD Publications.

McNiff, J. (1991). Action Research: Principles and Practices. New York: Routledge.

Mills, Geoffry E. (2003). Action Research: A Guide for the Teacher Researcher. Ohio: Merrill Prentice Hall, second edition.
Slamet, Margono. (2009). Perkembangan Penyuluhan: Teori dan Praktek. Bogor: Penerbit IPB [Institut Pertanian Bogor]. Tersedia secara online juga di: http://margonoipb.wordpress.com/category/ makalah-makalah/penyuluhan-teori-dan-praktek/ [diakses di Pekan Baru, Indonesia: 15 April 2016]. Sudjana, Nana. (2006). Penilaian Hasil Proses BelajarMengajar. Bandung: Penerbit PT Rosdakarya.

Sudjana, Nana. (2009). Dasar-dasar Proses BelajarMengajar. Bandung: Penerbit Sinar Baru Argensindo.

Triningsih, Diah E. (2014). "Model Penemuan Terbimbing untuk Mengidentifikasi Kekurangan Teks Prosedur Siswa Kelas VIII SMPN I Karangploso" dalam Jurnal Lingua, Vol.13, No.1 [Maret], hlm.73-86, e-ISSN 2442-238x.

Yamin, Martinis. (2009). Strategi Pembelajaran Berbasis Kompetensi. Jakarta: Penerbit Gaung Persada Press. 
ROZA YULIDA, KAUSAR \& YULIA ANDRIANI,

Penggunaan Model Pembelajaran Penemuan Terbimbing

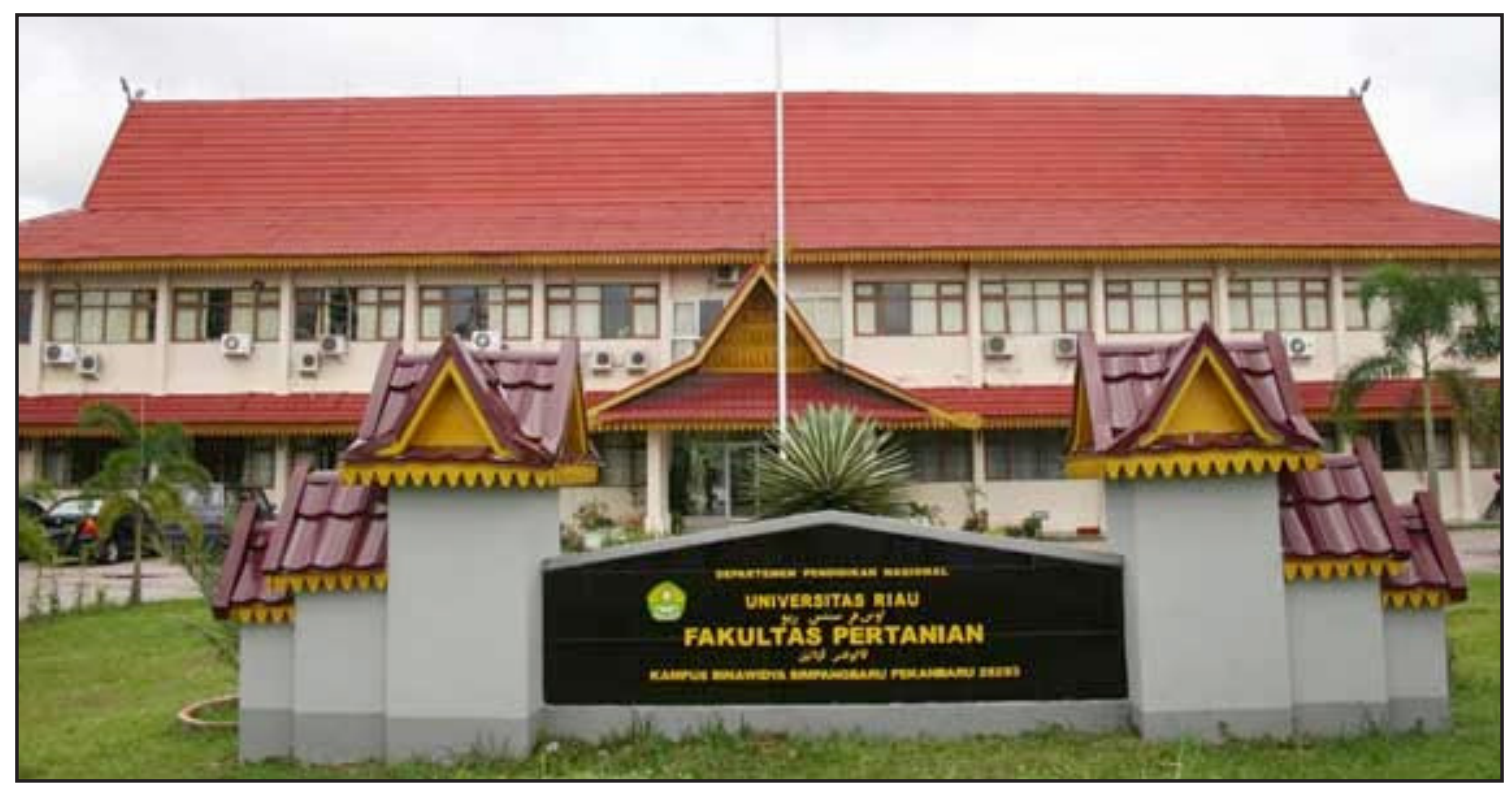

Fakultas Pertanian UNRI

(Sumber: http://tokoilmulo.blogspot.co.id, 2/5/2016)

Matakuliah Penyuluhan dan Komunikasi Pertanian merupakan matakuliah wajib pada Jurusan Agribisnis, Fakultas Pertanian UNRI (Universitas Riau) di Kota Pekanbaru, Provinsi Riau, Indonesia. Berdasarkan pengalaman mengajar di Fakultas Pertanian UNRI, mahasiswa masih cenderung pasif, karena lebih banyak tergantung pada apa yang diperintahkan oleh dosen. Rendahnya aktivitas belajar mahasiswa pada matakuliah Penyuluhan dan Komunikasi Pertanian, menjadi salah satu penyebab rendahnya hasil belajar mahasiswa. 